\title{
PHOSPHATURIC MESENCHYMAL TUMOUR ASSOCIATED WITH OSTEOMALACIA: A CASE REPORT
}

Veena Jeyaraj1, Kiruthiga Kala Gnanasekaran², Anne Jennifer Premkumar³

\section{HOW TO CITE THIS ARTICLE:}

Veena Jeyaraj, Kiruthiga Kala Gnanasekaran, Anne Jennifer Premkumar. "Phosphaturic Mesenchymal Tumour Associated with Osteomalacia: A Case Report". Journal of Evolution of Medical and Dental Sciences 2015; Vol. 4, Issue 17, February 26; Page: 3017-3020, D0I: 10.14260/jemds/2015/438

ABSTRACT: Phosphaturic mesenchymal tumour is a tumour that can involve bone or soft tissue. This is a rare tumour and is known to be associated with osteomalasia. This is caused by tumour induced expression of fibroblastic growth factor (FGF23). We present a case of PMT in a 72 year old female patient who was diagnosed with osteomalasia due to nutritional deficiency of vitamin D and was appropriately treated but later presented with a mass in her foot.

KEYWORDS: Phosphaturic mesenchymal tumour, osteomalacia, FGF-23, histology.

INTRODUCTION: Phosphaturic mesenchymal tumour is a cause of tumour induced osteomalasia (TIO) which is a well-known para neoplastic association. In addition to symptoms of bone pain, muscle weakness and tenderness biochemical studies reveal hypophosphaturia, inappropriate phosphaturia and raised levels of fibroblastic growth factor(FGF-23).(1) The tumour could involve any site. Microscopy reveals a tumour with sheets of spindle shaped to stellate cells in a myxoid matrix and flocculent or grungy calcification with giant cell response.(2)

CASE REPORT: A 72-year old lady presented with complaints of generalized weakness, bone pain, difficulty in ambulation and gradual loss of weight. Her laboratory parameters revealed hypocalcemia and hence a diagnosis of osteomalacia due to nutritional deficiency of vitamin D was made and she was appropriately treated. Three years later, the patient came back with persisting symptoms and recurrent swelling in the right foot. Examination revealed a small swelling of size $4 \mathrm{~cm}$ in the plantar aspect of the ball of big toe of the right foot. Biochemical investigations revealed hypophosphatemia, hyperphosphaturia, normocalcemia and normocalciuria. Her FGF 23 levels were markedly elevated.

The lesion in the right foot was biopsied and sent for histo pathological examination. The H\&E stained slides revealed fragments of a tumour composed of sheets of spindle to polygonal cells with indistinct cytoplasm and ovoid to plump predominantly vesicular nuclei and inconspicuous nucleoli. Several blood vessels were seen dispersed within the tumour. Osteoclast type of giant cells, several foci calcification including grungy calcification, recent and old haemorrhage and focal microcystic change were noted. Mitotic figures were not seen. Hence a diagnosis of phosphaturic mesenchymal tumour-mixed connective tissue variant was made.

DISCUSSION: Phosphaturic mesenchymal tumour is a rare soft tissue neoplasm that most commonly presents as osteomalacia. Oncogenic osteomalacia is the most common presentation of this tumour. The patients usually present with symptoms related to hypophosphatemia that include extreme muscle weakness, bone pain and tenderness, fracture, skeletal deformities, disturbed gait and loss of height. This hypophosphatemic osteomalacia is a rare para neoplastic syndrome induced by the production of fibroblast growth factor 23 (FGF 23). FGF 23 is a protein involved in the regulation of 
serum phosphate and calcitriol.(3) It interacts with the sodium-phosphate co-transporter in the renal tubular epithelial cells and inhibits the absorption of phosphate.

These groups of neoplasms present most commonly in early to mid-adulthood, although any age group may be affected and there is no sex predilection. The most frequent site of involvement is the lower extremity (40-50\%). However, the other common sites of occurrence of these tumours are head and neck, trunk and upper extremity.(4) Unusual sites of involvement include the cranio-facial sinuses, meninges.(4)(5)(6) They present as small non-specific soft tissue masses.

The biochemical profile in these patients point towards an hypocalcemic, hypophosphatemic state with low calcitriol (1,25- dihydroxy vitamin D) and normal levels of 25-hydroxy vitamin D.(5)

Oncogenic osteomalacia is a heterogenous entity which can be precipitated by various tumours of the breast, prostate, small cell carcinoma, myeloma etc.(6) The tumours associated with oncogenic osteomalacia have been classified into 4 groups by Weidner and Santa-Cruz as primitive appearing mixed connective tissue tumours, osteoblastoma-like tumours, non-ossifying fibroma like tumours and ossifying fibroma like tumours. Of these, mesenchymal phosphaturic tumour has been included in the first group and is labeled as phosphaturic mesenchymal tumour - mixed connective tissue variant. (7)

Histologically these tumours have the following characteristic features which aid in the diagnosis - hypo cellular tumour composed of bland appearing spindle shaped to stellate cells with small nuclei, inconspicuous nucleoli and eosinophilic cytoplasm, hyalinised to myxoid appearing matrix which undergoes calcification in a flocculent fashion also described as grungy calcification eliciting a giant cell response of the osteoclast type. A well-developed capillary network resembling haemangio - pericytoma is classically seen in almost all the cases.(8)(2) The other features include the presence of microcystic spaces, osteoid and cartilaginous metaplasia, histiocytes and presence of mature adipocytes within the tumour. The absence of necrosis and mitosis point towards a benign nature of the tumour. However, the presence of nuclear atypia, mitosis and other sarcomatous features point towards malignant transformation of an otherwise benign entity. There were no features of malignancy in this biopsy sample.

Tumour induced osteomalacia may be extremely debilitating; however there is a drastic reversal of the biochemical parameters, signs and symptoms following excision of the lesion.

We conclude that the pathologists should be aware of the clinical features and the metabolic profile of the patient to make a correct diagnosis of this rare entity.

Fig. 1: Phosphaturic mesenchymal tumour - Mixed connective tissue type with sheets of spindle shaped cells with elongate with focally hyalinised matrix and "grungy" calcification.

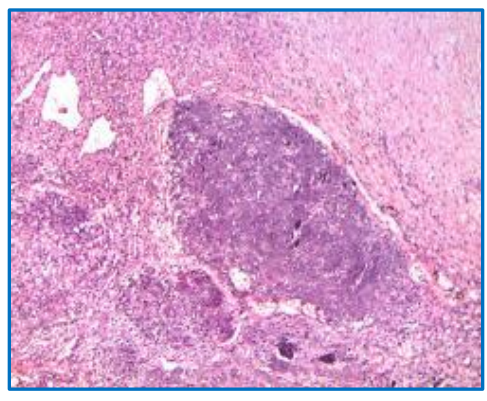

Fig. 1 


\section{CASE REPORT}

Fig. 2: Phosphaturic mesenchymal tumour - Mixed connective tissue type with "grungy" calcification, rich capillary network and few giant cells.

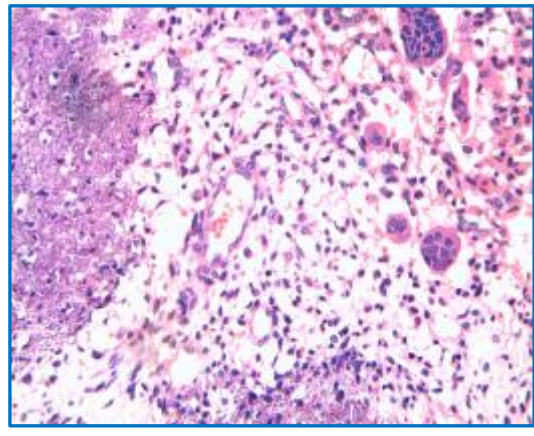

Fig. 2

\section{REFERENCES:}

1. Pirola E, Vergani F, Casiraghi P, Leone EB, Guerra P, Sganzerla EP. Oncogenic osteomalacia caused by a phosphaturic mesenchymal tumor of the thoracic spine. J Neurosurg Spine. 2009 Apr 1; 10(4):329-33.

2. Folpe AL, Fanburg-Smith JC, Billings SD, Bisceglia M, Bertoni F, Cho JY, et al. Most osteomalaciaassociated mesenchymal tumors are a single histopathologic entity: an analysis of 32 cases and a comprehensive review of the literature. Am J Surg Pathol. 2004 Jan; 28(1):1-30.

3. Jüppner H. Phosphate and FGF-23. Kidney Int. 2011 Apr; 79(S121):S24-7.

4. Guglielmi G, Bisceglia M, Scillitani A, Folpe AL. Oncogenic osteomalacia due to phosphaturic mesenchymal tumor of the craniofacial sinuses. Clin Cases Miner Bone Metab. 2011; 8(2):45-9.

5. David K, Revesz T, Kratimenos G, Krausz T, Crockard HA. Oncogenic osteomalacia associated with a meningeal phosphaturic mesenchymal tumor. J Neurosurg. 1996 Feb 1; 84(2):288-92.

6. Final Diagnosis -- Case 360 [Internet]. [cited 2015 Feb 3]. Available from: http://path.upmc.edu/cases/case360/dx.html.

7. Weidner N, Santa Cruz D. Phosphaturic mesenchymal tumors. A polymorphous group causing osteomalacia or rickets. Cancer. 1987 Apr 15; 59(8):1442-54.

8. The WHO Classification of Tumours of Soft Tissue and Bone (Sarcomas) [Internet]. Liddy Shriver Sarcoma Initiative. [Cited 2015 Jan 3]. Available from:

http://sarcomahelp.org/reviews/who-classification-sarcomas.html. 


\section{CASE REPORT}

\section{AUTHORS:}

1. Veena Jeyaraj

2. Kiruthiga Kala Gnanasekaran

3. Anne Jennifer Premkumar

\section{PARTICULARS OF CONTRIBUTORS:}

1. Grade II Assistant Professor, Department of General Pathology, Christian Medical College, Vellore.

2. Post Graduate Tutor, Department of General Pathology, Christian Medical College, Vellore.

3. Grade I Associate Professor, Department of General Pathology, Christian Medical College, Vellore.

\section{NAME ADDRESS EMAIL ID OF THE CORRESPONDING AUTHOR:}

Veena Jeyaraj,

Department of General Pathology, $4^{\text {th }}$ Floor, ASHA Building, Christian Medical College, Hospital, Vellore-632004, Tamil Nadu.

E-mail: veenajeyaraj@gmail.com

Date of Submission: 02/02/2015.

Date of Peer Review: 03/02/2015.

Date of Acceptance: 17/02/2015.

Date of Publishing: 26/02/2015. 